Almana : Jurnal Manajemen dan Bisnis Vol. 4 No. 2/ Agustus 2020

ISSN 2579-4892 print/ ISSN 2655-8327 online

\title{
The Influence of Motivation on Employees Performance
}

\author{
Intan Anas Tasya*1, Alini Gilang² \\ Universitas Telkom, Indonesia \\ ianastasyaintan@gmail.com*1, alinigilang55@gmail.com²
}

\begin{abstract}
The role of human resources is crucial for the realization of the company's goals to find optimal profits. At this time, employees will be motivated if needs are met, if needs are met then job satisfaction will arise which will have a positive impact on the work needs of employees at the company. This study aims to study the work motivation of employees of PT. Taspen (Persero) Bandung Main Branch Office. The method used in this research is quantitative with a descriptive research type. Respondents in this study were 51 employees of PT. Taspen (Persero) Bandung Main Branch Office, sampling method Saturated sampling technique. Based on the results of research that shows motivation and performance at PT. Taspen (Persero) Bandung Main Branch Office is included in both categories. The results also showed motivation for employee performance. Besides, contributing motivation in contributing to employee performance by $33.8 \%$. So the higher the motivation provided, the higher the employee's performance.
\end{abstract}

Keywords: Motivation, Employee Performance

\section{INTRODUCTION}

Every company that is founded has goals that are expected in the future will enhance development that increases its commitment as stated in the vision and mission of an organization or company. However, in the process, companies need superior human resources $(H R)$ as a key element in achieving success. PT. Taspen (Persero) Bandung Main Branch Office is engaged in old-age insurance and Civil Servant insurance (PNS) insurance funds. According to Larasati \& Gilang (2014) company goals, companies are required to be able to approve, improve, and improve the quality of support they have. One way that companies can do to improve quality is to pay attention to the motivation of their employees".

Motivation according to Mangkunegara (2013) "is formed from the attitudes (attitudes) of employees in changing jobs in the company (situation). Motivation is a condition or energy that drives employees who are directed or directed to achieve the goals of the organization of the company. Mental attitudes of employees who are pro and positive towards work that supports motivation to achieve maximum performance". In this case, motivation plays a role in improving employee performance. If there is a loss of motivation it will have an impact on this performance proving what is meant by motivation with performance. The less motivation, company performance will decline. As Asim said (2013) " if the motivation level was increasing, if the organization stands on every step, the performance was increasing. Motivation level is the direct and positive relationship with the employee performance", the struggle for motivation increases, and the struggle to achieve its needs will improve employee performance. By providing work motivation is expected to increase company productivity so that it can compete and provide the best for consumers.

So it can be denied that the company can improve the quality of employees one of them by providing work motivation to employees while motivation is expected to be one of the factors to improve performance in the company. So it can be concluded that a company can improve the quality of employees one of them by providing work motivation to employees where motivation is expected to be one of the factors to improve performance in the 
company. The study aims to analyze the effect of Work Motivation effect on employee performance in PT. Taspen (Persero) Bandung branches main office.

\section{METHODS}

The research method used is quantitative research methods. The population in this study were employees of PT. Taspen (Persero) Bandung Main Branch Office which arrested 51 people. This study uses saturated samples as a sampling technique so that the samples taken are 51 people taken samples. The sampling in this study was carried out using saturated sampling techniques. Saturated sampling is a sampling technique if all members of the population are sampled, Sugiyono (2012) Taspen (Persero) KCU Bandung with a total of 51 people. Data needed in research is quantitative data that requires primary data. Primary data obtained through direct interviews and through the distribution of questionnaires which are questions in the form of questions raised to the sample based on details of each variable used in the research model.
Also with secondary data in the form of explanations or existing literature answered with research. Secondary data is data obtained through literature study with various writings through books, journals, and so on to support research. This study uses a simple regression analysis technique used to study the strong influence of independent variables on the dependent variable. According to Sugiyono (2017) "simple regression is based on the functional or causal relationship of an independent variable with a dependent variable". In doing regression calculations, the IBM SPSS Statistics 22 Software is used to measure the effect of the independent variable with the dependent variable.

\section{RESULTS AND DISCUSSION}

This study uses the Simple Linear Regression Analysis. In doing regression calculations, the IBM SPSS Statistics 22 Software is used to measure the effect of the independent variable with the dependent variable. The calculation results can be seen in the table below:

Table 1. Test Results of the Fourth Week of Effects

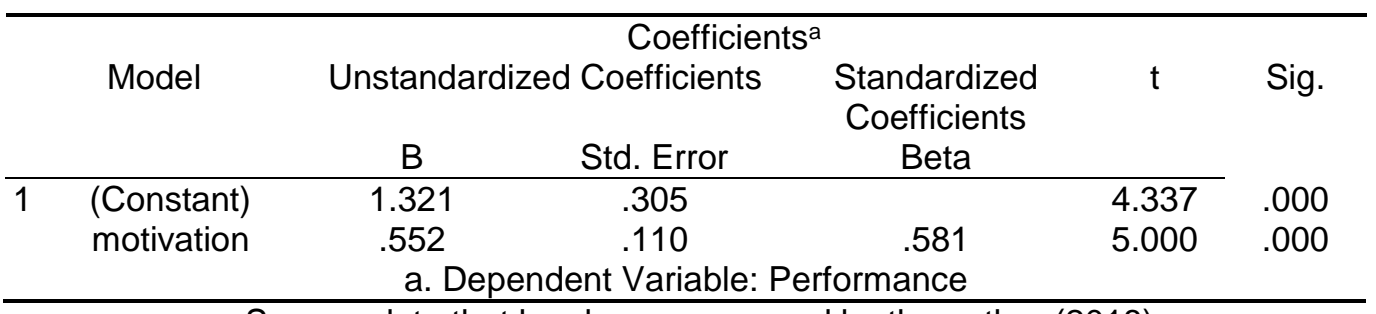

Source: data that has been processed by the author (2018)

From the above equation can be explained as follows:

Constants $(a)=1,321$. This shows the constant value if the employee motivation variable $(X)=0$, then the employee's performance (Y) at PT. Taspen (Persero) KCU Bandung remains at 1,321 . This means that if the $\mathrm{Y}$ variable, namely employee performance is not influenced by the independent variable, namely employee work motivation $(X)$ is zero, then the average value of employee performance is 1.321 .

Coefficient $X(b)=0.552$. This shows that if employee motivation (X) increases by one unit, employee performance $(\mathrm{Y})$ will increase by 0.552 . 
So from the simple linear regression coefficient test results above are positive, which means that the performance of employees at PT. Taspen (Persero) KCU Bandung is influenced by employee motivation (the higher the employee motivation, the more employee performance increases).

Hypothesis testing is used to determine whether motivation has a significant relationship or not with the performance of employees of PT. Taspen (Persero) Bandung Main Branch Office. An explanatory or independent variable depends on the individual in explaining the variation of the dependent variable.

Testing this hypothesis is carried out through statistical tests using the IBM SPSS Statistics 22 Software, which is for training purposes related to employee improvement. The following is the t-test results table:

Tabel 2. T-test results

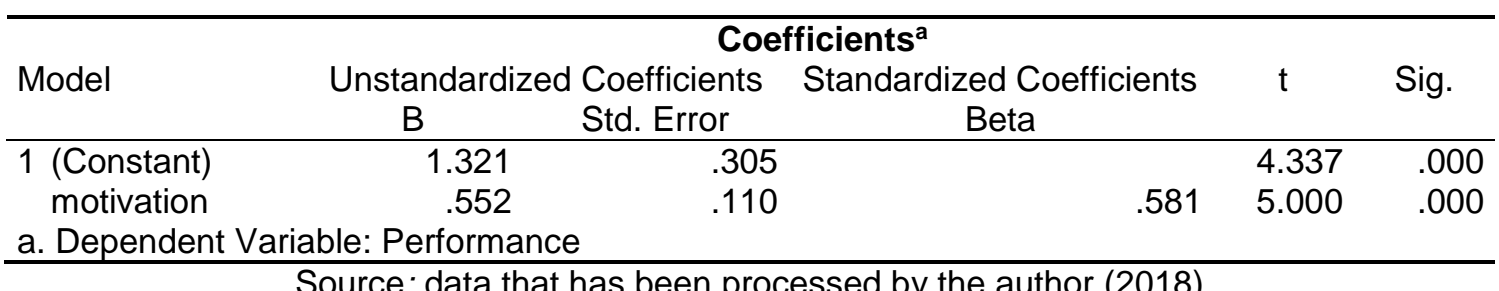

Based on Table 2 above, the calculated $t$ value of 5,000 is obtained, while the $\mathrm{t}$ table is 2.063 with a significance level of $5 \%$. So it can be interpreted that $\mathrm{HO}$ is rejected and $\mathrm{H} 1$ is accepted, so it can be concluded that motivation has a significant effect on the performance of employees of PT.
Taspen (Persero) Bandung Main Branch Office.

The coefficient of determination is used to understand the contribution of the independent variable $(X)$, which is training on the dependent variable $(Y)$, namely employee performance. The calculation results $R^{2}$ can be seen in the table below:

Tabel 3. Coefficient of determination

\begin{tabular}{lccccr}
\hline Model & \multicolumn{4}{c}{ Model Summary $^{\mathbf{b}}$} & \multicolumn{2}{c}{ R Square } & $\begin{array}{c}\text { Adjusted R } \\
\text { Square }\end{array}$ & $\begin{array}{c}\text { Std. Error of } \\
\text { the Estimate }\end{array}$ & Durbin-Watson \\
\hline 1 & & .524 & .40798 & 1.503 \\
$\begin{array}{l}\text { a. Predictors: (Constant), motivation } \\
\text { b. Dependent Variable: Performance }\end{array}$ & .338 & & & & \\
\hline
\end{tabular}

Source: data that has been processed by the author (2018)

The coefficient of determination formula is $\mathrm{KD}=\mathrm{r}^{2} \times 100 \%$. Based on the results of the coefficient of determination test known value $r^{2}=0,581$. Then the calculation of the coefficient of determination is as follows:

$$
K D=(0,581)^{2} \times 100 \%=33.8 \%
$$

This figure shows the coefficient of determination (KD) of $33.8 \%$. This shows that the amount of training contribution to the performance of the employees of PT. Taspen (Persero) Bandung Main Branch Office by 33.8\% and the remaining $66.2 \%$ influenced by other variables not examined. 


\section{CONCLUSION}

Based on the results of data analysis and discussion that had been completed in the previous chapter, the conclusion is Motivation at PT. Taspen (Persero) Bandung Main Branch Office as a whole is included in the good category. The performance of the employees of PT. Taspen (Persero) Bandung Main Branch Office as a whole is included in the good category. Based on the results of testing has been proven about motivation and a significant impact on the performance of employees of PT. Taspen (Persero) Bandung Main Branch Office.

\section{REFERENCES}

Asim, M. (2013). Impact of Motivation on Employee Performance with Effect of Training: Specific to Education
Sector of Pakistan. International Journal of Scientific and Research Publications, 3(9), 2250-3153.

Larasati, S., \& Gilang, A. (2014). Pengaruh Motivasi Kerja Terhadap Kinerja Karyawan Wilayah Telkom Jabar Barat Utara (Witel Bekasi). Jurnal Manajemen dan Organisasi, 5(3), 200-213.

Mangkunegara. (2013). Manajemen Sumber Daya Manusia. Bandung: PT. Remaja Rosda Karya.

Sugiyono. (2012). Metode Penelitian Kuantitatif, Kualitatif dan $R \& D$. Bandung: Alfabeta.

Sugiyono. (2017). Statistika Untuk Penelitian. Bandung: Alfabeta. 